\title{
Kirjoituskutsu Kirjallisuudentutkimuksen aikakauslehti Avaimen vuoden 2020 numeroihin 2 ja 3
}

Kutsumme kirjoittajia Avaimen vuoden 2020 toiseen ja kolmanteen numeroon. Numeroilla ei ole erityisiä teemoja. Toivotamme tervetulleiksi kirjallisuudentutkimukseen liittyviä - myös moni- tai poikkitieteellisiä - artikkeleita sekä muita kirjallisuutta ja kirjallista elämää käsitteleviä esseitä, katsauksia, puheenvuoroja, haastatteluja ja kirja-arvosteluja. Arvosteluja toivomme niin kotimaisesta kuin ulkomaisesta tutkimuskirjallisuudesta tai muusta kirjallisuustieteellisestä julkaisusta. Otamme myös jatkuvasti vastaan julkaisuehdotuksia artikkeleista, arvosteluista ja muista teksteistä.

Refereeartikkeleiksi tarkoitetut käsikirjoitukset ovat pituudeltaan $20000-$ 40000 merkkiä välilyönteineen. Kirja-arvostelujen ohjepituus on 5000-7000 merkkiä välilyönteineen. Katsauksien, esseiden ja muiden vapaamuotoisempien kirjoitusten laajuudesta sovitaan päätoimittajien kanssa. Avaimen ohjeet kirjoittajille löytyvät lehden journal.fi-sivuilta: https://journal.fi/avain/about/ submissions.

Numeron 2/2020 artikkeliehdotusten deadline on 1.4.2020. Muiden kirjoitusten deadline on 22.4.2020.

Numeron 3/2020 artikkeliehdotusten deadline on 8.6.2020. Muiden kirjoitusten deadline on 17.8.2020.

Ehdotukset refereeartikkeleiksi lähetetään sähköisesti valmiin käsikirjoituksen muodossa, ei abstraktimuotoisena. Ehdotukset esseiden, katsausten, arvostelujen ja haastattelujen aiheista voivat olla vapaamuotoisempia.

Avain käyttää digitaalista OJS-julkaisujärjestelmää journal.fi. Järjestelmää käytetään myös lehden toimitustyössä. Pyydämme lehden lukijoita ja kirjoittajia kirjautumaan järjestelmään journal.fi-sivuston kautta ja tarjoamaan artikkeleita, arvosteluja ja muita puheenvuoroja sen kautta. Mikäli kirjautumisessa on ongelmia, pyydämme teitä ottamaan yhteyttä toimitussihteeriin (jari.kakela@ gmail.com). Kirjoituksia koskevissa muissa kysymyksissä ottakaa yhteyttä päätoimittajiin. 